\title{
INIERF-SPACQ
}

\section{WATER RESOURCES AVAILABLE AT CISTERNS IN THE ACARAÚ RIVER BASIN, CEARÁ, BRAZIL}

\section{OS RECURSOS HÍDRICOS EXISTENTES NAS CISTERNAS DE PLACAS DA BACIA HIDROGRÁFICA DO RIO ACARAÚ, CEARÁ BRASIL}

\section{LOS RECURSOS HÍDRICOS EN LAS CISTERNAS DE PLACAS DE LA CUENCA HIDROGRÁFICA DEL RÍO ACARAÚ, CEARÁ BRASIL}

\begin{abstract}
José Falcão Sobrinho
Doutor em Geografia Física pela Universidade de São Paulo - USP. Pós-Doutor em Geografia pela Universidade Federal do Ceará - UFC. Professor Associado e Coordenador do Programa de PósGraduação em Geografia da Universidade Estadual Vale do Acaraú - UVA. falcao.sobral@gmail.com / http://orcid.org/0000-0001-6335-6088
\end{abstract}

Recebido para avaliação em 28/06/2020; Aceito para publicação em 26/12/2020.

\section{ABSTRACT}

The proposition of this work consists of research carried out in the Acaraú River basin, popularly known as Vale do Acaraú, which is located in the State of Ceará and belongs to the Brazilian Northeast region. At the time, water was given priority as the object of study, highlighting the social technology focused on cisterns. Three areas of different geomorphological environments were delimited by the spatial cutout, in the respective municipalities, which were: humid residual massif, in Serra da Meruoca; sertaneja surface, in Reriutaba; and, coastal zone, in Marco. On that occasion, families were interviewed, more specifically, those living in the communities that favor the benefits of cisterns resulting from the Programa Um Milhão de Cisternas (A Million Cisterns program, P1MC). Improvement consistent with the quality of life of the communities benefited could be noted, as well as the understanding that there is a likelihood of permanent actions aimed at the adequate care of this new element incorporated into the natural landscape and the daily life of such communities.

Keywords: Vale do Acaraú; Cisterns; Relief; P1MC; Physical Geography.

\section{RESUMO}

A propositura do trabalho em questão consiste em pesquisa realizada na bacia hidrográfica do Rio Acaraú, popularmente, conhecida por Vale do Acaraú, localizada no Estado do Ceará, pertencente à Região Nordeste do Brasil. Na ocasião, privilegiou-se a água, como objeto de estudo, destacando-se a tecnologia social, voltada à cisterna de placa. O recorte espacial delimitou três áreas de ambientes geomorfológicos distintos, nos respectivos municípios, quais sejam: maciço residual úmido, na Serra da Meruoca; superfície sertaneja, em Reriutaba; e, zona litorânea, em Marco. Na oportunidade, foram entrevistadas famílias, em comunidades que, favorecem-se dos benefícios das cisternas, decorrentes do Programa Um Milhão de Cisternas (P1MC). Na ocasião, constataram-se melhorias condizentes com a qualidade de vida das comunidades beneficiadas, como também, possibilitou-se o entendimento de que, há a probabilidade de se ocorrerem ações permanentes, destinadas ao adequado zelo desse novo elemento, incorporado na paisagem natural e, no cotidiano de tais comunidades.

Palavras-chave: Vale do Acaraú; Cisterna de Placa; Relevo; P1MC; Geografia Física. 


\section{RESUMEN}

El objetivo del trabajo en cuestión consiste en la investigación realizada en la cuenca hidrográfica del río Acaraú, popularmente conocida como Vale do Acaraú, ubicada en el estado de Ceará, perteneciente a la región noreste de Brasil. En ese momento, el agua era privilegiada como objeto de estudio, con énfasis en la tecnología social, centrada en la cisterna de placas. El contorno espacial delimitó tres áreas de entornos geomorfológicos distintos, en los municipios respectivos, a saber: macizo residual húmedo, en Serra da Meruoca; campo, en Reriutaba; y, zona costera, en Marco. En la ocasión, se entrevistó a familias en comunidades que se benefician de los beneficios de las cisternas, como resultado del Programa One Million Cisterns (P1MC). En esa ocasión, se encontraron mejoras en línea con la calidad de vida de las comunidades beneficiadas, además de permitir comprender que existe la posibilidad de acciones permanentes, dirigidas al cuidado adecuado de este nuevo elemento, i ncorporado al paisaje natural y, en la vida cotidiana de tales comunidades.

Palabras clave: Vale do Acaraú; Cisternas de Placas; Alívio; P1MC; Geografía Física.

\section{INTRODUÇÃO}

Historically, the Brazilian Northeast portion is a region that suffers from water shortage due to irregular precipitation levels in space and time. In some periods, rainfall is torrential and concentrated in specific areas, which occurs the most in humid residual massifs and coastal zones, whereas it is scarce with constant drought, mainly in the sertaneja surface.

This problem has been part of the northeastern context for centuries and, especially in the semiarid region, is followed by a population that resists the irregularity of rainfall, the water shortage and other conditions associated with the water condition, for example, the lack of food, health and work.

The adoption of numerous government projects and programs came as an attempt to minimize the effects of this problem. One of these projects was the construction of dams, which was monitored by the Instituto de Obras Contra as Secas (Institute of Works to fight the Drought, IOCS) along with the Instituto Federal Contra a Seca (Federal Institute to fight the drought, IFOCS) and the Departamento de Obras Contra a Seca (Department of Works to Fight the Drought, DNOCS).

Dams in the northeastern region, including those in Ceará, may be classified into two principal types. The first one covers medium and large reservoirs, which can store billions of cubic meters of water and, the second one covers small reservoirs, which are quite common in that region and hold hundreds of thousands of cubic meters of water (Cirilo, 2008). The spatial dimension in the construction of the dams involved areas such as the sertaneja surface, the humid residual massif and the coastal zone. 
However, this solution was not enough to serve the entire population, since much of the stored water, mainly from public reservoirs, is distributed to urban areas. On the other hand, the areas surrounding the dams are properties destined for irrigation, belonging to large landowners.

Such situations pervade the northeastern space and, especially, the semiarid Ceará, in its various environments, the ones prioritized here mentioning geomorphologic compartments. Be it in the relief altitudes, in the sinuosity and plaining, the rhythms and processes that manifest the so-called natural elements and the already modified natures, are in a constant reorganization of new landscape scenarios. From this, there is a link between dams and distant communities from them, which occurs through the tank truck, an alternative that is part of the public policies of the water resources of the northeastern people. It happens that, with the tank truck, this element (water) is transported, many times, without the due care regarding the hygiene, to attend the need of one or several communities.

However, what must be realized is how the interaction between nature and humans needs to be improved due to its effects over environments, including over that one that sustains it, seeking to create a proper setting for the natural/social balance.

This fact became clear in specific actions with the active participation of the communities. Silva et al. (2009) affirm that the failure model of works gave rise, in the 1990s, to innovative ideas that aimed to take advantage of scarce water resources in the semiarid northeastern region. Those resources, in turn, are originated mainly from rainfall and that, because they were not taken advantage of, they were wasted. For this reason, in periods of drought, the rural population often ran out of water for their own consumption. In this paper, such practices are called coexistence with the semiarid region.

In this context, several techniques of coexistence with the semiarid region of Ceará are used precisely in the Acaraú river basin for water storage. The most known among them are a) small spatial coverage: cistern, well and underground reservoirs, which are known as social technology; and b) large spatial coverage: dams and reservoirs.

It is worth mentioning that the cisterns considered in this article are partially buried, cylindrical-shaped and covered with cement. They propitiate the collection and storage of rainwater that is collected from the top of the houses through gutters made of zinc or PVC.

In this sense, the referred research aims to analyze the use of cisterns, in different geomorphological environments, along the Acaraú river Basin, selecting a municipality, in each environment: Meruoca, in the residual massif; Reriutaba, in the sertaneja surface; and 


\section{|José Falcão Sobrinho|}

Marco, in the coastal zone (Figure 1). Other experiences, attested in research, are recorded in the course of the valley (FALCÃO SOBRINHO et al. 2015); (ALMEIDA; FALCÃO SOBRINHO, 2015 and 2016).

The analyzed area, that is, the Acaraú river basin, will be referred to from now on by Vale do Acaraú, as it is popularly known and already named in the studies of Falcão Sobrinho (2006). Vale do Acaraú, in the State of Ceará, is between the geographical coordinates: from $02^{\circ} 47^{\prime}$ to $04^{\circ} 58^{\prime}$ latitude south and from $39^{\circ} 40^{\prime}$ to $40^{\circ} 51^{\prime}$ longitude west. Regarding geomorphologic characteristics, the area is comprised of high reliefs above 1000 $\mathrm{m}$, the so-called humid residual massif, and low reliefs of up to $400 \mathrm{~m}$. These reliefs occupy about $90 \%$ of the valley designated as sertaneja surface, besides the coastal zone.

In such geomorphological environments, the distribution of the municipalities along the valley is as follows: a) humid residual massif: Meruoca, in Serra da Meruoca, and Monsenhor Tabosa, in Serra das Matas; b) sertaneja surface: Catunda, Cariré, Forquilha, Graça, Groaíras, Hidrolândia, Ipu, Ipueiras, Massapê, Mucambo, Nova Russas, Pacujá, Pires Ferreira, Reriutaba, Santana do Acaraú, Sobral, Santa Quitéria, Tamboril and Varjota; and c) coastal zone: Acaraú, Bela Cruz, Cruz, Marco and Morrinhos, totaling more than $90 \%$ of the total area inserted in the semiarid environment.

Figure 1 - Acaraú river basin and the studied municipalities (own photo)

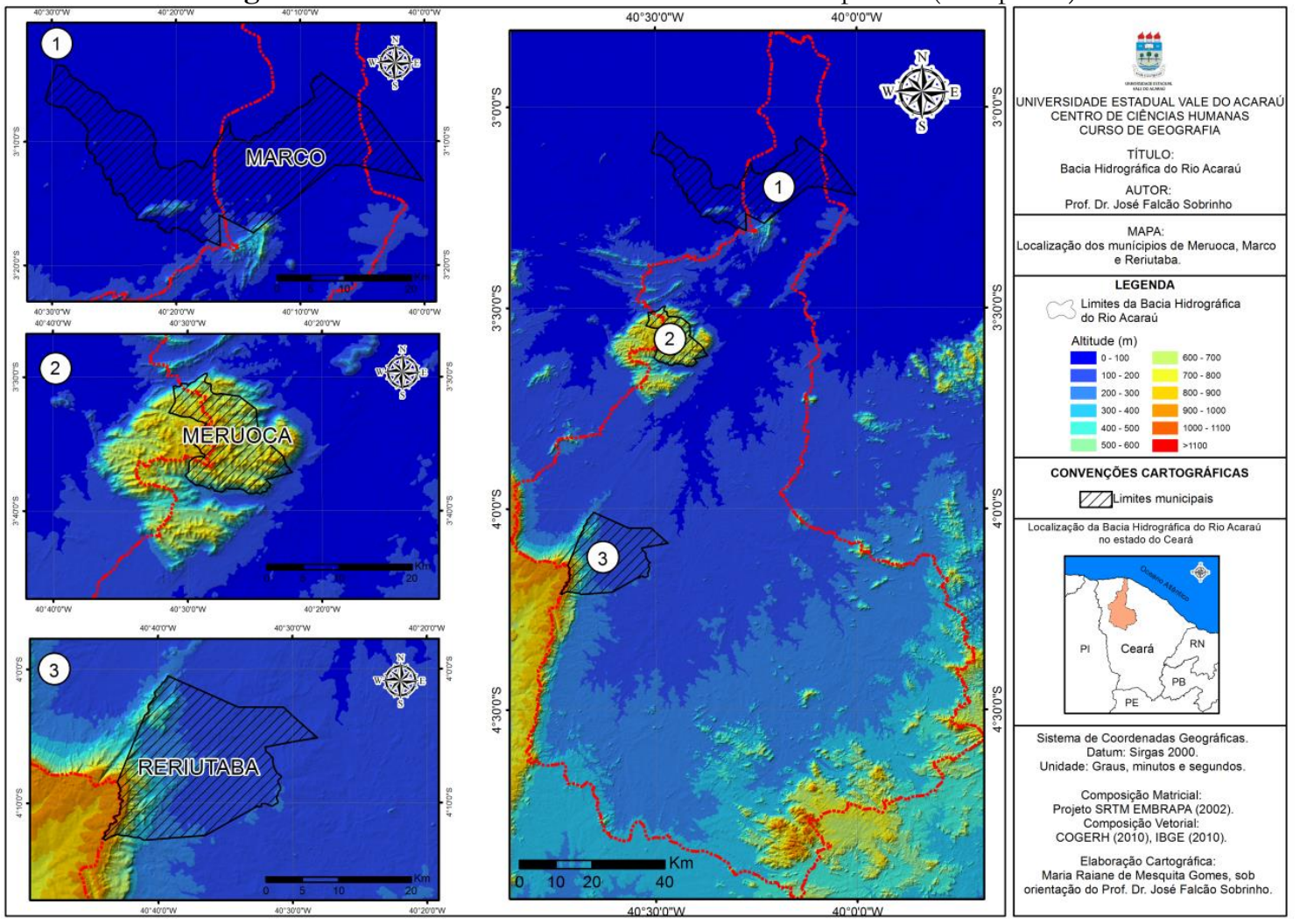


The first to be addressed here is the water, which is part of the landscape, since the relief, as a spatial dimension, is cartographically possible of delimitation and comprehension in the organization of the landscape in its natural aspects and cultural diversities. In this article, the water will be analyzed beyond its natural context, that is, as a guiding element of scenarios in which cultural landscapes are visualized.

\section{THE WATER POLICY IN VALE DO ACARAÚ}

The remarkable characteristic of the public policies, focused on irrigation and implemented in the semiarid region, is accompanied by large water infrastructures usually allocated near vast farms. Surrounding the farms, it is noticeable the concentration of power and the economic and political dependence of poor families for access to water sources.

It is evident that during the projects and programs against the drought, the Brazilian State was undoubtedly the only responsible for the creation and execution of public policies for the semiarid region. The exclusive action of the Brazilian government, in the construction of large water infrastructure works, organization of work front and distribution of water and food, represented the existence of a "state monopoly" in the planning and execution of public policies in the region (PONTES; MACHADO, 2009).

In the context of the insertion of large dams directed to irrigation activities, shown in Table 1, an intense change in the natural landscape can be observed over time with the insertion of crops, unknown to the local population, a fact evaluated in the irrigated perimeter in Varjota, the perimeter of Araras, and in Marco, in the perimeter of lower Acaraú. However, this public policy of dams does not meet the needs of a large part of the population, especially the ones who live in the countryside. 
|José Falcão Sobrinho|

Table 1 - Distribuition of dams in Vale do Acaraú

\begin{tabular}{|l|l|r|}
\hline \multicolumn{1}{|c|}{ Dam } & \multicolumn{1}{c|}{ Municipality } & Capacity $\mathbf{( m}^{\mathbf{3}} \mathbf{)}$ \\
\hline Acaraú Mirim & Massapê & 52.000 .000 \\
\hline Araras (Paulo Sarasate) & Varjota & 891.000 .000 \\
\hline Arrebita & Forquilha & 15.600 .000 \\
\hline Jaibaras (Ayres de Souza) & Sobral & 104.430 .000 \\
\hline Bonito & Ipu & 6.000 .000 \\
\hline Carão & Tamboril & 26.230 .000 \\
\hline Taquara & Cariré & 320.000 .000 \\
\hline Edson Queiros & Santa Quitéria & 254.000 .000 \\
\hline Farias Lima & Nova Russas & 12.300 .000 \\
\hline Forquilha & Forquilha & 50.130 .000 \\
\hline São Vicente & Santana do Acaraú & 9.840 .000 \\
\hline Sobral & Sobral & 4.675 .000 \\
\hline Carminha & Catunda & 13.628 .000 \\
\hline \multicolumn{2}{|c|}{ TOTAL } & $\mathbf{1 . 7 6 3 . 7 6 3 . 0 0 0}$ \\
\hline
\end{tabular}

Note: Table made by the authors of this research.

The perception also causes the migration of the local community, especially farmers who once lived in areas taken for the insertion of companies. Most of this migration is promoted by the production system, which does not resemble the reality of the local producer. Such socio-environmental problems accentuate the historical social difference and degrade the rural environment. It leads to review Herrera (1979), who argues that countries develop technology more adherent to local realities. To this end, in his view, it would be necessary to formulate the method of research and development in science and technology, to enable the emergence of a set of endogenously generated assumptions or paradigms that can serve as a basic framework to develop technology destined to needs and aspirations.

Therefore, irrigation projects in the semiarid region of Brazil symbolize a success for the supply of some cities, business profitability, as well as the supply of products that surround the region. It is also counted on the increase of the local trade, through the commercialized inputs in the city, dynamizing the trade and hotel sectors.

The centralized water supply, through extensive dams and pipelines, is centered on policies, historically emergency, formulated and implemented without the participation of citizens.

During government actions imposed mainly by DNOCS and the Superintendência do Desenvolvimento do Nordeste (Oversight of the Norhteastern Development, SUDENE), the Articulação no Semiárido Brasileiro (Works in the Brazilian Semiarid Region, ASA) emerged in the period between the late 1990s and early 2000s. This advent represented a deepening of civil society participation, reflecting and executing 


\section{|José Falcão Sobrinho|}

actions aimed at the reality of the semiarid environment, especially the issue of water, as a vital product for human need.

Since its foundation, ASA's work (2002) has already had numerous permanent proposals for coexistence with the Brazilian semiarid region, covering all the municipalities in Vale do Acaraú. In terms of results and dissemination, P1MC is also a highlight.

To understand how these cisterns are, they are buried in the ground to about twothirds of its height and made of concrete plates ranging from 50 to $60 \mathrm{~cm}$ and, commonly, $3 \mathrm{~cm}$ thick are required. These plates are curved depending on the radius of the cistern wall, which based on the community participation, is manufactured on the place of installation using wooden molds. The cistern wall is raised using thin plates from the cemented floor. Subsequently, a wire is rolled up on the outer side of the wall and then plastered. Finally, the roof is built using pre-molded plates by placing them on top of reinforced concrete beams and plaster from the outside. P1MC focuses on the construction of one million cisterns, as seen in the prototype (Figures 2 and 3).

The model of each cistern can store sixteen thousand liters of water, covering the supply of a family of five people during the eight months of drought, bearing in mind that this water is intended exclusively for human consumption, which consists of drinking and cooking.

It adds that such a claim must occur throughout the semiarid region guaranteeing quality water for the consumption of approximately five million people. According to the ASA's report (2002), the program establishes for the rural communities, a process of qualification aiming at the coexistence with the semiarid that intends to involve, directly, one million families.

In this process, coexistence is approached when focusing, specifically, on the management of water resources, the construction of cisterns, water policies, management of public resources and the financial administration of the resources coming from P1MC.

Figure 2-Construction process of the cisterns. Figure 3-A model of the cistern (ASA, 2002).
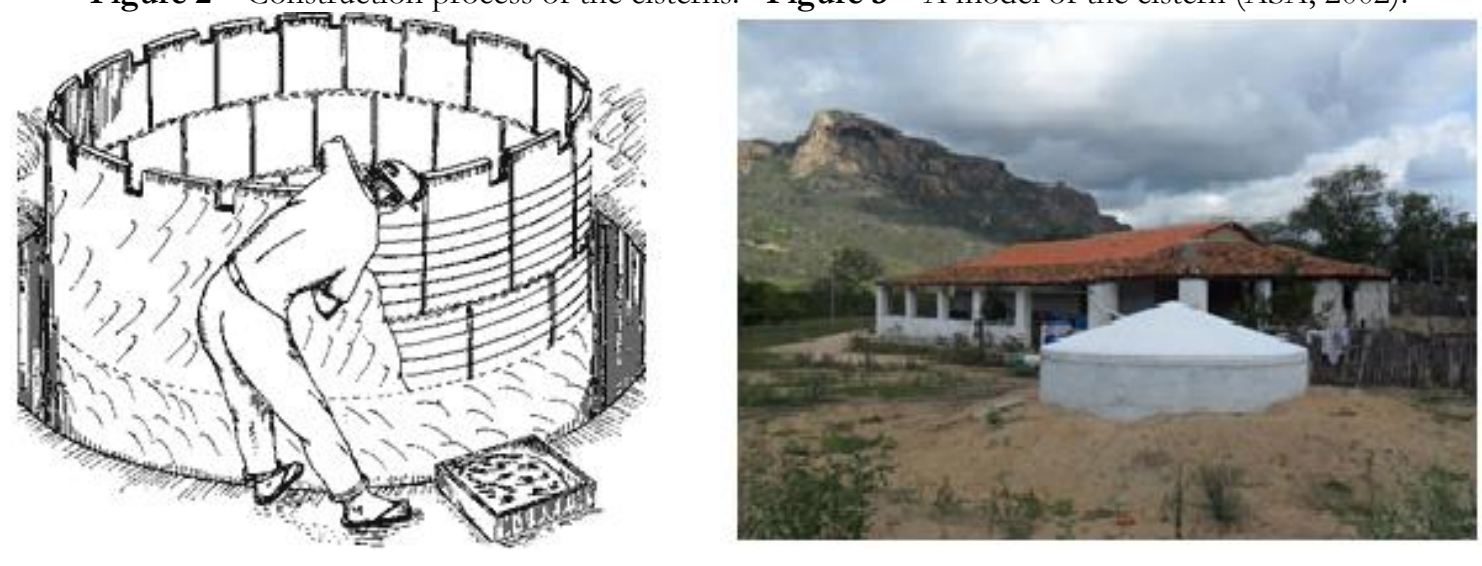
It is worth mentioning that $\mathrm{P} 1 \mathrm{MC}$ is not a program that brings together the whole community involved. Instead, it is a program that includes the awareness of its preservation and socialization. P1MC provides the articulation of the community, inserting it in the practice of coexistence with the semiarid region by training families through the organization of the civil society through unions, NGOs, associations, churches, among others. In due time, courses are given for the development of the activities. This is in line with what Hjern \& Porter (1993) suggests when they mention that public policies are implemented by various participants who build implementation structures based on their interactions. This multiplicity of participants must be considered when thinking about social technology as an object of public policy, which necessarily refers to the concept of state action that incorporates OSCs as key participants in the provision of public goods and services.

This model is based on the criticism of the approach, currently employed, related to the fight against drought. Therefore, it does not obey the conventional character that was, historically, built in the course of the semiarid northeastern region.

ASA has been working with P1MC since 2000, when it signed an agreement with the Ministério do Meio Ambiente (Ministry of the Environment, MMA). The P1MC continues to be supported, institutionally, by the Federal Government, through the Ministério do Desenvolvimento Social e Combate à Fome (Ministry of the Social Development and Actions to Fight Hunger, MDS, 2006), as part of the program Fome Zero (No Hunger).

The proposal of P1MC disseminates the knowledge about the construction, management and productive use of social technology of coexistence with the semiarid region by training and aggregating families (bricklayers, social technicians, amongst others) and promoting the exchange of experiences. In this premise, new public policy options are discussed, developed, organized and established to expand access to water for low-income families in the semiarid region of Brazil, basically social technology, earned for the production of food for self-consumption, prioritizing food security and sovereignty.

Concerning the development of the implementation of the national policy of social technology, foreseen by bill no. 111/2011 (FEDERAL SENATE), social technology is conceived as a set of activities developed through a collective process of organization, development and application that can combine popular knowledge, social organization and technical-scientific knowledge.

These procedures are aimed at social inclusion and the improvement of the quality of life, generating effective social transformation, inherent to planning, research, 
development, creation, application, adaptation, dissemination and evaluation of the following prerogatives: a) techniques, procedures and methodologies; b) products, devices, equipment and processes; c) services; and d) social, organizational and management innovations.

According to ASA (2014), about the basic requirements required to assist rural families, those who, in addition to being included in the Cadastro Único para Programas Sociais (Register for Social Programs, CadÚnico), have access to water, intended for human consumption, are favored, as an example, P1MC cisterns; women as householder; children aged between zero and six years old; children and teenagers who attend school; adults aged 65 years or older and people with special needs.

Concerning the choice of the appropriate technology, the characteristics of soils are considered, such as the rock formation (crystalline, sedimentary, sandstone); and the type of activity to be developed.

It appears that, with this low level of rainfall, in addition to poor distribution, the Federal Government has instituted programs for the construction of cisterns to alleviate the water shortage for families in the semiarid northeastern region, such as the P1MC and the MDS cisterns program. (ALVARGONZALEZ, 1984).

The author also points out that in the region, issues related to the use of water address one of the most controversial issues. It is a phenomenon that has been aggravated by the global environmental tension and that configures the forms of occupation of the region by limiting or developing a structure favored by the policies to combat drought.

\section{WATER HARVESTING AROUND THE WORLD}

The human development report, published by UNDP (2006), reports on the problem of water resources at a global level, as well as alternatives for training through social technologies or conventional techniques, such as the construction of dams. Along with these issues, there is a concern, at an international level, with climate change and its reflection on sustainability, which is focused on the relationship between society and nature. However, it is noted that the United Nations Framework Convention on Climate Change (UNFCCC) was created in 1992 with the focus on addressing the risk represented by global climate change (FORD et al., 2010), associating the lack of fresh water.

However, this treatment of the lack of water resources associated with climate change has been the protagonist and not solved, when the subject is an adaptation (SCHIPPER, 2006). 
In this perspective of adaptation, Adger \& Kelly (1999) put forward that the question encompasses a set of perspectives that move between more social and more biophysical approaches, since they are grouped under the scope of social vulnerability, addressing vulnerability as a social construction of historical roots and economic, political and cultural causes that reduce the capacity of systems to prevent or respond satisfactorily to external impacts.

Also, in this search, Negev \& Gibson (2001) indicate different studies on the beginning of the use of rainwater harvesting and storage technology, being the first rainwater storage cisterns built around 2,000 B.C., in Palestine. Along the same lines, Wahlin (1995) points out as the oldest record the existence of a sophisticated water harvesting system that was planned and built before 3,000 B.C. in the Black Desert in the Northeast of Jordan, as well as domestic cisterns in Palestine built during the same period.

Based on Ruskin (2001), the use of cisterns was the main source of water storage in the city of Venice, Italy, until approximately the 16th century. The practice of rainwater harvesting was intense in the city for over 1,300 years, and water was stored in 177 public cisterns and 1,900 private cisterns.

Gnadlinger (2001) and UNEP (2002) report that China is traditionally a country that has accumulated a great deal of experience in agriculture and climate practices, where the use of rainwater can be found in several parts of the country. Such practices are essential to the development of agricultural activities, since more than $60 \%$ of its territory is subject to climates of considerable aridity, being 19.5\% semiarid, 13\% arid and 29\% superarid. Gansu province is one of the poorest and most ecologically fragile in the country, where water shortage represents a limiting factor for rural development and the standard of living of the population.

Also noteworthy is the UNICEF report (2002), addressing the use of jars as a public water supply policy in Thailand in the 1980s, which was called the Rainwater Jar Programme. Since then, until 1991, thousands of jars for rainwater storage were built. Rainwater was collected from the top of houses to meet the domestic water needs of some rural families.

\section{CHARACTERIZATION OF THE ANALYZED AREAS}

Because of the context presented here, it is necessary to address how water resources overlap with the relief, constituting several scenarios, in the landscape arranged. The result of this process goes against the use of the water by the users. 


\section{|José Falcão Sobrinho|}

As the average rainfall level for the last twenty-one years is over $800 \mathrm{~mm}$ and, according to Figure 4, only in the period from 1995 to 2009, showed high values, mainly in the residual massif of Meruoca. It can be seen that, in subsequent years, there were oscillations, with most of these values referring to the last ten years, indicating an index below $800 \mathrm{~mm}$, stressing the last six years. These sudden variations, in their pluviosity, cause problems of water scarcity, in some years, and floods, in others.

Figure 4 - Rainfall levels in 22 years in Meruoca, Marco and Reriutaba

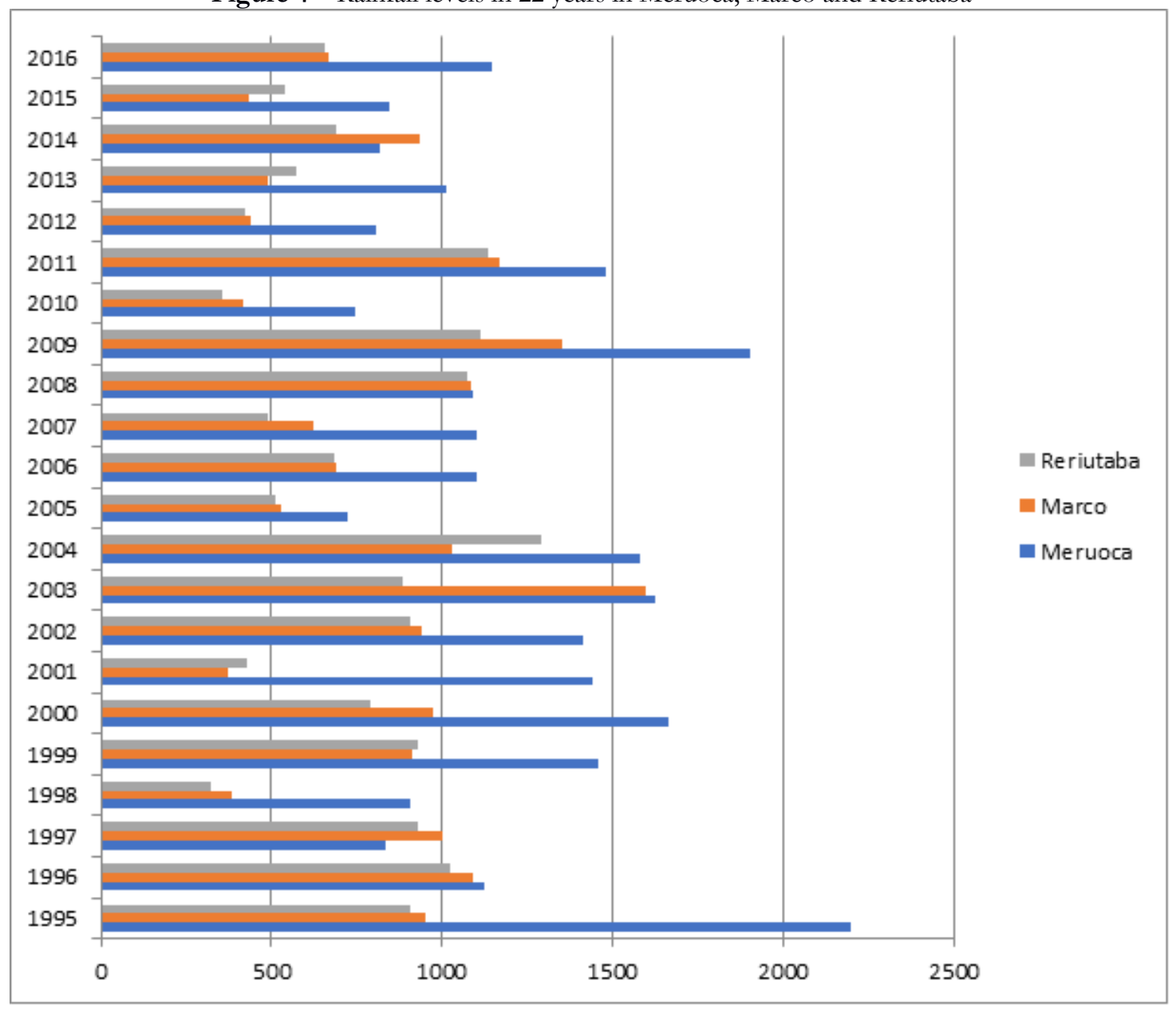

Source: (FUNCEME, 2016).

It is noticeable that, in general, the areas are characterized by irregular rainfall in time and space, with the rainy season being concentrated in the first months of the year and presenting a water deficit most of the year. As a rule, the municipality of Meruoca portrays a relevant water reserve, followed by Marco in the coastal zone and finally Reriutaba in the sertaneja surface. The figures below illustrate this information.

Figure 5 shows the possibility of detecting that potential evapotranspiration was higher than actual evapotranspiration from June to December, especially in Meruoca. As 
for the municipalities of Marco and Reriutaba, the water deficit started in May. This fact is equivalent to the condition of precipitation that also ceases from May.

Figure 5 - Water balance of Meruoca, Reriutaba and Marco, pespectivelu (own photo).

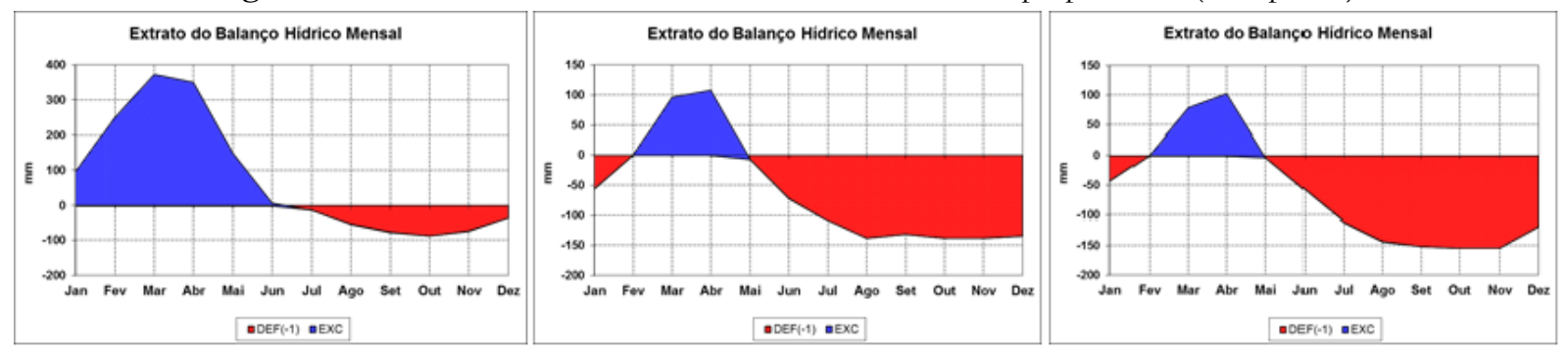

It is important to note that the dry season in the semiarid region of Ceará occurs in the second half of the year, which culminates in the meeting of the water shortage conditions in the State, a situation that justifies considerably the construction of cisterns.

Meruoca. The word "Meruoca" is of indigenous origin and means "home for flies" due to the number of flies that existed in that region. Meruoca is in the northwestern portion of Ceará, in the humid zone, has an average altitude above 700-800 meters from sea level and points to the following geographical coordinates: Lat (S): $3^{\circ} 32^{\prime} 3^{\prime \prime}$; and, Lon (WGr): $40^{\circ} 27^{\prime} 18^{\prime \prime}$.

According to Costa Falcão (2008), due to its high relief, Serra da Meruoca determines the alteration of climatic conditions, opposes the displacement of air currents and consequently displays a humid phase (windward) and another almost dry phase (leeward). This panorama favors a greater precipitation and humidity recycling due to the constant formation of fog and dew, co-named hidden precipitation.

Due to the humidity conditions and the deep soils, associated to the precarious aspects of the local economy, subsistence agriculture is dominant and practiced in an improper way, which causes accentuated pedological losses due to culturally reproduced habits, through time, from generation to generation, such as burning, deforestation, among others. In this case, the water, so expected in the rainy season, becomes damage to the soil because it causes erosion.

Reriutaba. The municipality of Reriutaba is in the northwestern portion of Ceará, through the geographical coordinates: $4^{\circ} 08^{\prime} 30^{\prime \prime}$ south latitude; and, $40^{\circ} 34^{\prime} 06^{\prime \prime}$ west longitude. Its altimetry is close to 400 meters with conditions characterized by a hot semiarid climate and highlighted by poorly distributed rainfall in time and space, which covers a period of three to five months.

Currently, according to Fundação Cearense de Meteorologia e Recursos Hídricos (Ceará Foundation of Meteorology and Water Resources, FUNCEME), the water situation 
of Reriutaba is critical, as it is supplied by the Araras reservoir, which portrayed only $9 \%$ of its capacity on August 22, 2016.

The municipality is located on the sertaneja surface, where its water spreads through the cracks in the rocks, forming a tangle of channels with a detrital pattern that makes up the scenery and landscape. The greater or lesser porosity of the crystalline rocks interferes with the flow regime of the watercourses, considering that, in the rocks with a sandy texture, the infiltration reduces the superficial flow of the rivers making the regime more regular. As for the clay-textured rocks, the flow is predominantly superficial and the river regime is contrasted.

It is deduced that, for being directly influenced by the interaction of climatic, lithological and topographic factors, the hydrography of the area appears as one of its characteristic features, the preeminently temporary regime of the rivers that constitute it. This situation happens because it is an area where the yearly climatic rhythm is marked by the succession of rainy and dry periods. The water balance and the precipitation data, in Figure 5, of this environment, previously inserted, exactly manifest this situation.

Marco. The municipality of Marco is inserted in the coastal zone, at an altitude of $20 \mathrm{~m}$ above the sea, is located between the geographical coordinates, now delineated: $03^{\circ}$ 07' 26" South latitude; and, 40 08' 48" West longitude.

The coastal plains are made up of sediments of the Barreiras group from the PlioPleistocene epoch and they represent the most typical deposition glacis of Ceará. Leaning gently from the countryside to the coast, the tableland surface is almost always below 100 $\mathrm{m}$ of altitude, as is the case in the municipality of Marco.

With poor drainage, the coastal tableland is made up of wide stretches of horizontal surfaces separated by slopes that are not very pronounced, hence the inoperative character of interfluves. According to Souza (1988), tableland areas, in a generalized way, represent a typical deposition glacis, furrowed by drainage, which demands the coast, isolating tableland-shaped interfluves. Part of this conjuncture is the popular term "tabuleiros" (tableland), enshrined by the Brazilian geographic literature.

In Marco, the pre-coastal zones expose the types of soils that stand out the most, which are Alluvial Neosol, Regolith Neosol, Quartzarenic Neosol and Acrisol. In a general context, the caatinga vegetation is present in this environment, intercalating the carnauba vegetation.

\section{MATERIAL AND METHOD}


For methodological purposes, the principles of Ab'Saber (1999) were consulted, when he treated relief as a fundamental element for the adequacy of nature to the investments of public policies in the Brazilian northeastern region. Hence, in each methodological compartmentalization, an application of public policies appropriate to them stands out. Thus, it was associated with the understanding of Falcão Sobrinho (2007); Falcão Sobrinho (2020), emphasizing the relief as an anchor of the landscape and, in each compartmentalization of the relief is the appropriate scenario for anthropic activities, associating the natural characteristics that it has. That said, the studied areas were: Meruoca, a humid residual massif environment; Reriutaba, a municipality located on the sertaneja surface, and Marco, a municipality located in the coastal zone of Ceará, Brazil. This is because, in the context of the semiarid region in the Northeast of Brazil, several municipalities are inserted in it and distributed in the various geomorphological compartments suggested in this research.

The particularities of the interpretation of the natural characteristics of environments were based on the general systems theory, proposed by Bertalanffy in 1936. In the opportunity, each element was associated with the other, and in the flow of matter and energy, the attributes of the elements provide the necessary dynamics for their balance.

The author assesses that the perspective of its application is of a general character so that it can be applied to quite similar phenomena that occur in a diversity of specific fields of knowledge. In this case, such similarities are detected in each compartmentalization of the relief.

Based on the selected municipalities and the need for knowledge and deepening of the information related to the object of study - the cisterns - the methodology of the MDS (2006) was adopted and adapted for the study in focus, with fieldwork and application of questionnaires to the communities assisted by the cisterns, totaling forty questionnaires, in each municipality.

However, it was necessary to analyze again the systemic understanding in the relations to be established in the sociocultural context with this new element in the landscape scenario, that is, the cistern. Such understanding was proposed by Buckley (1967), who, when dealing with systems theory in sociology, warns that the sociocultural system is an organic complex and the relations of the parts become more flexible as to the structure, hence the symbiosis nature and society.

\section{Fieldwork}


For data collection, a direct survey was conducted with families who have been served by cisterns for at least two years, based on interviews with qualitative and quantitative questions.

\section{Selection process of the areas in the municipality}

The communities were allocated, according to the natural territorial characteristics that comprise the sertaneja surface, humid residual massif and coastal zone, which, in turn, specify different conditions in terms of geomorphological and climatic conditions.

In addition, the following standards were established for the purposes of questionnaire conduction:
a) housing conditions, i.e. in rural areas;
b) socioeconomic characteristics of the dwellers;
c) work and income indicators;
d) alternatives for water acquisition.

For structural purposes, the following patterns were also evaluated:

a) the monitoring of the cisterns, by those who implemented it, observing if any cistern handling course was offered to the benefited community;

b) the evaluation of the water quality;

c) the form of repairs that may occur;

d) the current use of the cisterns;

f) the situation of the roofs of the houses.

The information mentioned herein does not constitute isolated answers, but it is fundamental that the set of information allows one to correlate them, besides corroborating evolutionary reflections for the improvement of the water harvesting system to the human consumption, even associating with the natural physical issues. For temporal purposes, families that have been served with cisterns at least two years ago are visited.

The knowledge experienced in the Acaraú river basin, in its natural and social aspects, can be examined in the works of Falcão Sobrinho (2008 and 2009) and Falcão Sobrinho \& Costa Falcão (2002).

\section{RESULT AND DISCUSSION}

In view of the data collected, it is identified that the cisterns have improved, notoriously, the reality of the communities served, regardless of the geomorphological compartments in which they are inserted. Therefore, the implantation of cisterns for the 


\section{|José Falcão Sobrinho|}

consumption of families that value them, as to their relevance, to soften the irregularities of rainfall, remains of great importance.

The served communities have a precarious level of education, making sure that, on average, $20 \%$ did not study, which contributes to some faults that can be seen from the handling of the cisterns, as shown in Figure 6(a).

Becoming a public policy that reflects benefits to the population, this system of treating rainwater or well water, in a water tank, also integrates an economy for the communities, since some families have little resources to buy drinkable water, or even to use tank trucks, as shown in Figure 6(b).

Figure 6- (a) level of education and (b) family income (own photo)

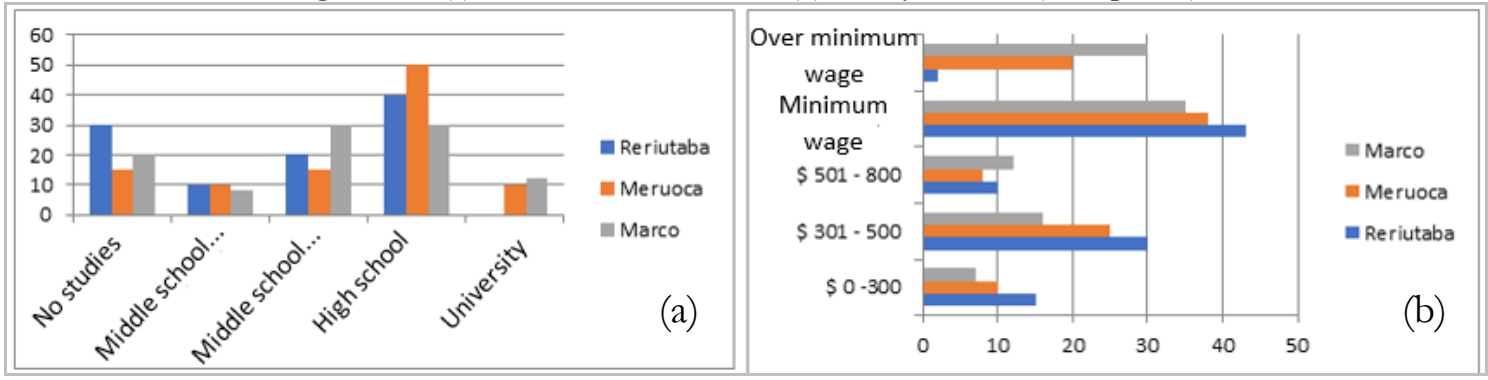

It is worth mentioning that several families who went to the cisterns lost contact with other environments, namely, the dams and weirs, in view of the distance, 5 to $10 \mathrm{~m}$, from the water to their houses. This phenomenon provokes a reflection, in a dissociation from nature. This being said, it is important to point out that fountains and trolleys are also included in water collection practices, as shown in Figure 7(a).

However, after the advent of the cisterns, the use of fountains and tank trucks remained for the communities, mainly during the dry season. Figure 7(b) supports this prism in percentage.

Figure 7 - (a) water from cisterns and (b) replacement of water in cisterns (own photo)

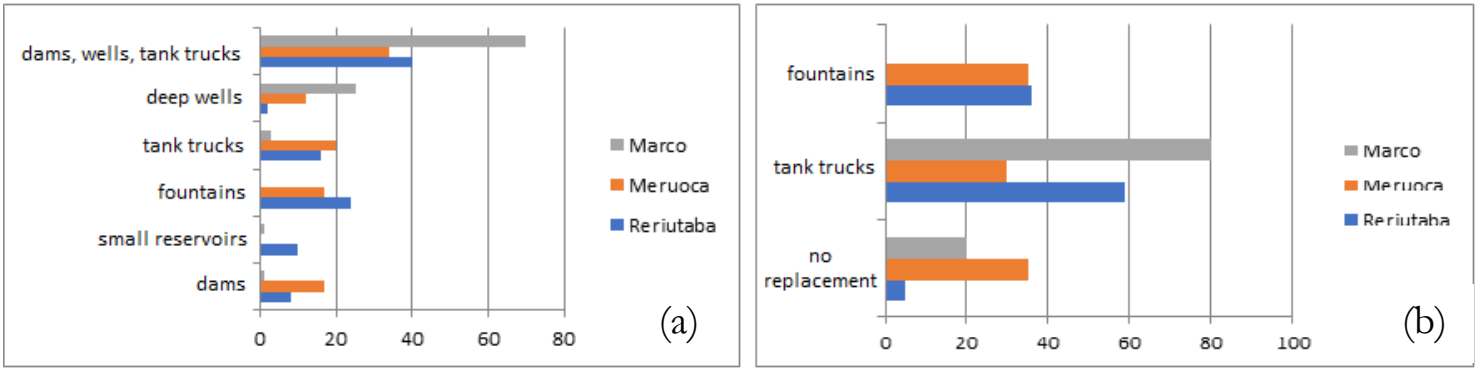

Therefore, it was evaluated that the locals use the cistern water resource in daily activities, not following the guideline of P1MC, according to which the water should be used for cooking and washing. 
Because of this aspect, it is understood that public policies, no matter how weighed up, in internal environments made up of competent technicians and professionals, conceive the realization that the reality of the communities benefited expresses the desires of the individual that go beyond those proposed. In this respect, the community of Marco is highlighted in Figure 8(a), and it is estimated that $40 \%$ of the beneficiaries preserve water only for drinking and cooking.

However, to consume the water from the cisterns, it is necessary to treat it. As Frazão (2016) explains, for contaminated water to become clean water for consumption, a solution with sodium hypochlorite must be used, available in pharmacies, supermarkets and also distributed by the government. The use of sodium hypochlorite is indicated to purify contaminated water, consisting of viruses, bacteria and fecal coliforms, which can happen in water from cisterns, small wells and in case of contaminated rainwater.

Figure 8(b) clarifies that several families follow this pattern for water treatment in the cistern.

Figure 8- (a) cistern water use and (b) water treatment (own photo)

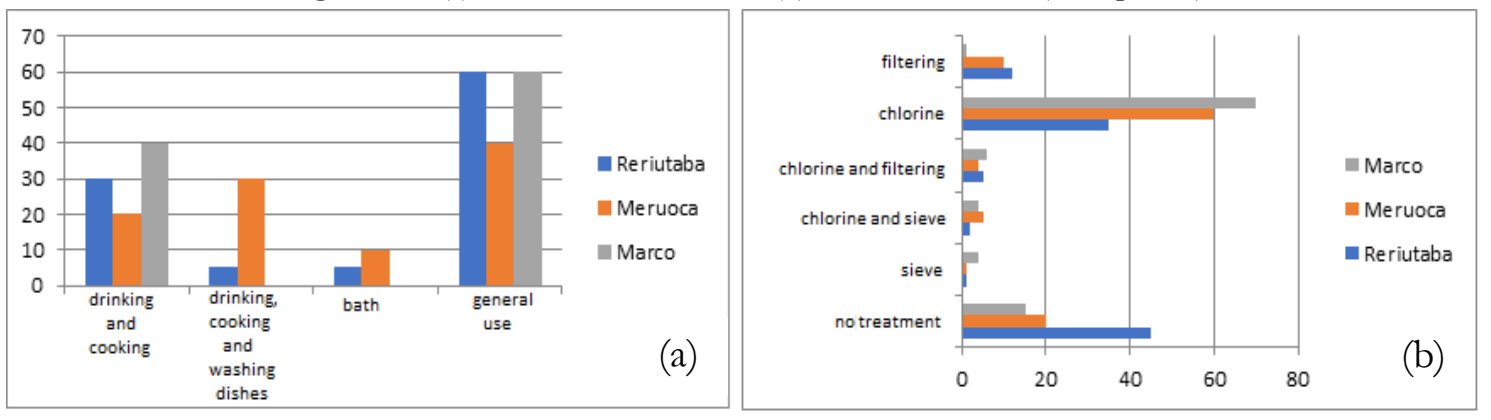

The same treatment with water should be closely followed in the maintenance of the cisterns because the use and forgetfulness may cause health problems. In time, the particles deposit themselves at the bottom of the cistern, producing sediment rich in organic matter, metals and probably resistant microorganisms highly harmful to human consumption.

Some studies, however, have shown that, in relation to physical-chemical factors, the contamination of rainwater in rural areas is low, usually meeting the standards of water for human consumption. The risks in water consumption are associated with microbiological contamination, as it depends both on the care taken in harvesting/storage and on correct handling (ANDRADE NETO, 2004). In this context, the use of cisterns is considered adequate, as illustrated in Figure 9(a).

It is worth pointing out that the cleaning method does not only include the outer environment, but also the inner one, as shown in Figure 9(b). In fact, microbial life may be 
housed in the outer walls, and it is appropriate to paint the walls, a fact that is verified by all the families benefited.

Figure 9- (a) inner cleaning and (b) painting of cisterns (own photo)
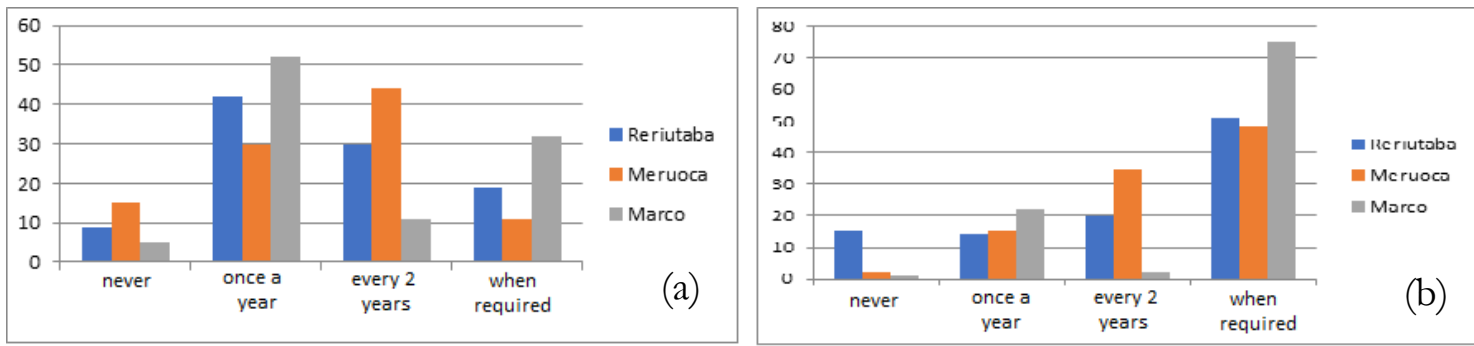

Such care takes into account the improvement of the quality of life of the population. From the perception, the water conditions, the damage caused to health due to lack of water or polluted water were examined, considering the fact that some diseases have already occurred related to the water consumed by the locals. The relevance of the cisterns in all households was highlighted since the residents reported that this was one of the main benefits for the people of Ceará, who did not know how life would be without the existence of these reservoirs, directed to the storage of water, as expressed by the data in Figure 10.

It can be concluded that these rates of improvement can be compared with previous data received in a period later than the use of cisterns when a high rate of diseases due to unhealthy water was present. The enlargement of P1MC and its impacts, in the transformation of the life of the inhabitants of the northeastern semiarid regions, is, therefore, a positive phenomenon that can make possible the permanence of the communities in the rural areas, potentializing an elevation of its standard of living, as a form to fight social exclusion, among the already existing ones (POCHMANN, 2004).

Figure 10 - (a) improvement of the quality of life after cisterns were implemented (\%) and (b) cases of health problems due to the lack of drinkable water (own photo)

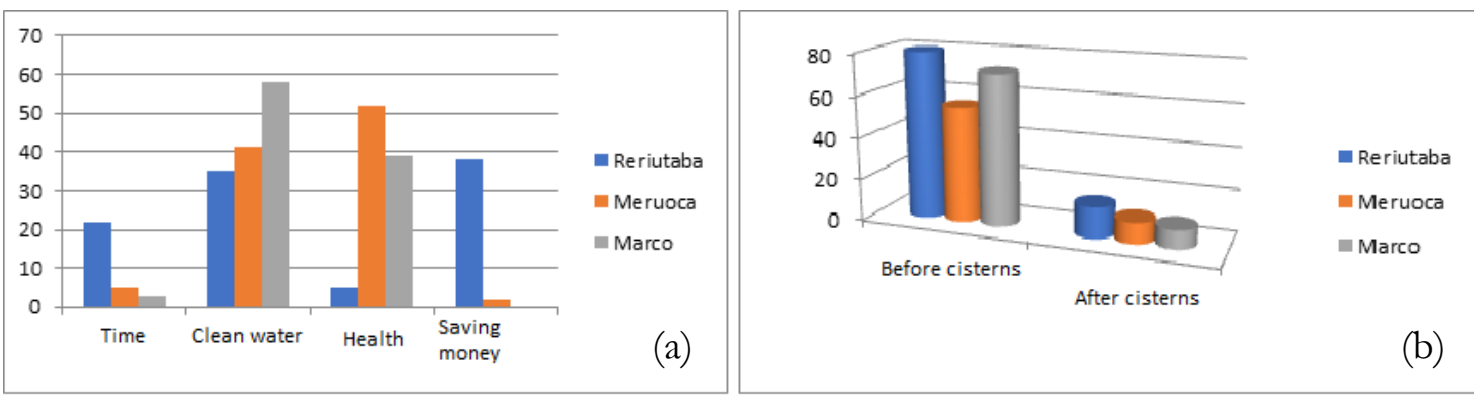


At a global level, the international literature presents important cases of technology related to water and sanitation that have brought improvements in the living conditions of communities, without the destruction of traditional values, and often enabling the generation of work and income. Such experiences include, for example, aquaculture techniques, rainwater harvesting, construction of water hand pumps, wells, cisterns, fountains, artificial lakes and water purification, filtration and desalination systems, contributing to the expansion of quality of life and health (DARROW; SAXENIAN, 1986).

It must also be verified that, given the data coming from the income of those families, in accordance with the level of education, the people's houses could cause damage to health, when collecting water, in view of the fact that the residences are mostly characterized as clay constructions. Figure 11(a) makes this representation available, allowing for the adoption of other precautions to be taken, especially with the initial water harvesting from cisterns.

In addition to the health problem, the importance of the time to be allocated to the water harvesting in the cistern by the community was noted. Ntale \& Moses (2003) analyzed rainwater collected from cisterns in Kampala, Uganda, comparing it with the quality of the first water retained by the diversion system and the water stored. The first ten minutes of rainfall, equivalent to $1,100 \mathrm{~mm}$, on a roof of $150 \mathrm{~m}^{2}$, was diverted and approximately 125 litres, of "dirty" water, were not captured.

The general rule is that the people who had benefited from the cisterns had a high level of awareness about water harvesting. Figure 11(b) proceeds with this situation.

Figure 11 - (a) building material and (b) water harvesting in cisterns (own photo)

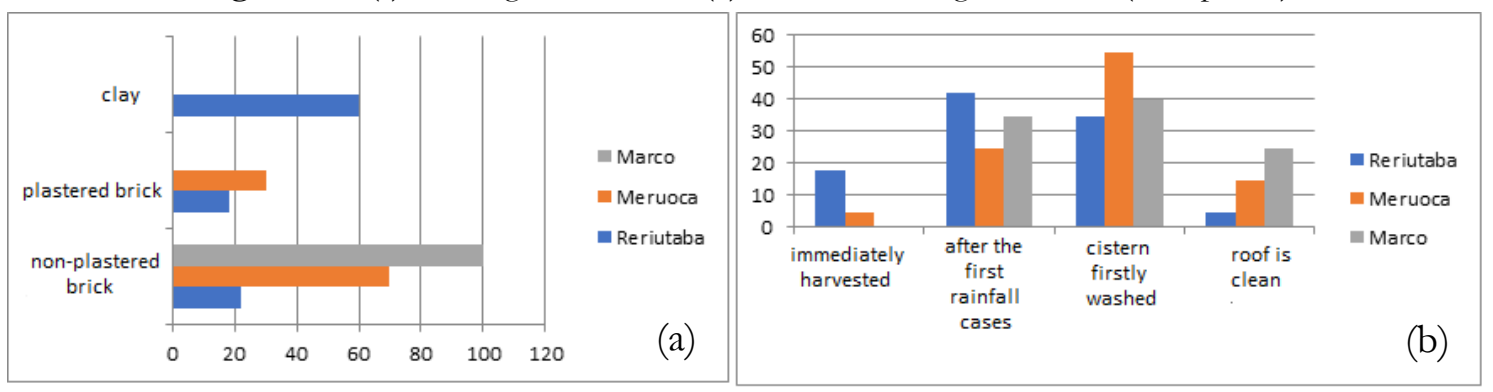

However, despite all the benefits that can be expressed, there are some issues, mainly related to the lack of continuity in the service to the communities, revealing that the project is carried out and then left to the care of the families. Such questions are checked in Figure 12(a), including the existence of cracks in the cisterns. 


\section{|José Falcão Sobrinho|}

According to Pineda (2013), most of the factors that can compromise the integrity of the cistern are integrated into the construction process. For this reason, every precaution must be taken regarding the quality of the materials and the construction process. Bad quality sand should not be used; building materials with the presence of organic matter; and traces of the slabs, the junctions of these slabs and the inadequate plaster, paying attention to other structural care.

It is also clear, as shown in Figure 12(b), that the benefit of the cisterns has been proven during the year, considering that drinkable water is now included in the homes attended by P1MC, over approximately eight months, with some cases in the coastal area, where the supply of surface water is concentrated annually.

Figure 12 - (a) cisterns problems and (b) period of water in cisterns after rainfall (own photo)

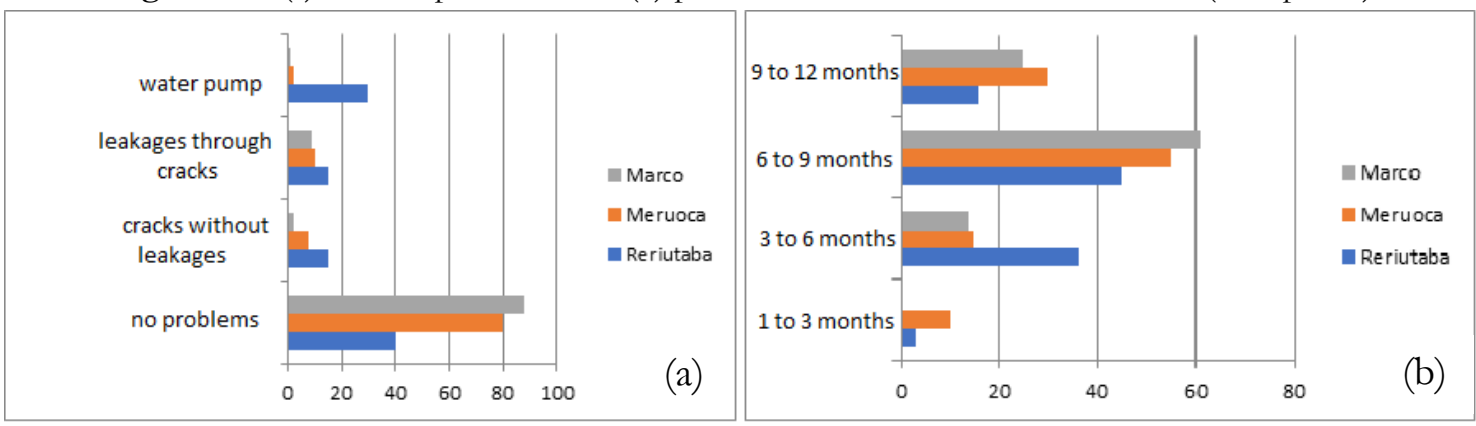

The period of water shortage in the semiarid regions, either in the environments of the humid residual massif, in the coastal zone or in the sertaneja surface, where the drinkable water appeared for a period of three to four months, was enlarged in relation to its focus of time, due to the fact that the notion of space became closer, denoting itself 3 to 5 meters from the residences, where the cisterns are located.

\section{FINAL CONSIDERATION}

The data obtained indicate that the population, in its majority and independent of the geomorphological environment, presents a low level of education and has economic conditions with income equivalent to a minimum wage. The majority of families are assisted by Federal Government programs.

It should be noted that cisterns, for families, are the main source of water, whether for drinking, as well as for developing domestic activities such as washing dishes and/or clothes. The difficulty of water due to rainfall occurs in the three areas analyzed, and the natural diversities present the same lack in terms of water resources. 
The importance of the cistern stands out, as it appears that diseases such as diarrhea, which was common in children, were reduced after the implementation of the cisterns.

For the construction of these cisterns, the residents had a minimum cost, which is, only the mason's payment. In the field, it is noted that almost $100 \%$ of the people in Vale do Acaraú region say that the coming of the cisterns to the houses represented an inseparable good since they can store water for consumption after the rainy period, that is, from February to May.

From the results of this research, the relevance of the cisterns for the communities is based, since the technology offered represents a benefit, because it provides good-quality water storage, according to the claims received. It is known that cisterns are the main source of water for human supply, due to the fact that the scarcity of this element in recent years has been devastating and causing problems for that population.

Before the implantation of the cisterns, diseases caused by water contamination were common and, with the implementation of this culture, there was a reduction of such diseases that harmed children.

Improvements in the standard of organization and solidarity among the members are observed in the communities. The use of cisterns is a simple, fast and efficient way to supply drinkable water to rural communities, improving the quality of life in the Brazilian semiarid region.

As the cistern system is a sealed treatment, there are no significant water losses due to evaporation, and water can be stored for almost the entire dry season if it is in a satisfactory state of conservation. This favoring relationship can be based on the high rates of evapotranspiration presented by the water balances of the three areas: mountain, sertaneja surface and coastal zone.

Since they are built close to houses, it is avoided that people have to travel long distances to buy water for daily consumption. In addition, if all necessary care is taken, rainwater, properly stored, may be of better quality to that from other sources. The great question is about the size of the cistern: could it be bigger and have a higher storage capacity than the current one?

\section{ACKNOWLEDGEMENT}

Thank to Conselho Nacional de Desenvolvimento Científico e Tecnológico (Nacional Council of Technologic and Scientific Development, CNPq) for the financial support. 


\section{REFERENCES}

AB'SÁBER, A. N. Sertões e sertanejos: uma geografia humana sofrida. Estudos Avançados, São Paulo, v. 13, n. 36, p. 7-59, may/aug. 1999.

ADGER, W. N.; KELLY, P. M. Social Vulnerability to Climate Change and the Architecture of Entitlements. Mitigation and Adaptation Strategies for Global Change, v. 4, n. 3/4, p. 253-266, 1999.

ALMEIDA, C. L; FALCÃO SOBRINHO, J. Os recursos hídricos do semiárido brasileiro e a questão das políticas públicas. In: CARACRISTI, I.; HOLANDA, V. C. C.; OLIVEIRA, M. L. V. M.; OLIVEIRA, F. S. (Org.). Diversidade socioespacial e questões ambientais do semiárido noroeste brasileiro. Sobral: UVA, 2016. 167 p.

ALMEIDA, C. L; FALCÃO SOBRINHO, J. As cisternas de placas no cenário da paisagem de superfície sertaneja no semiárido cearense. Fórum Ambiental da Alta Paulista, São Paulo, v. 11, p. 188-20, 2015.

ALVAGONZALEZ, R. O desenvolvimento do Nordeste árido. Fortaleza: DNOCS, 1984.

ANDRADE NETO, C. O. Proteção sanitária das cisternas rurais. In: SIMPÓSIO LUSOBRASILEIRO DE ENGENHARIA SANITÁRIA E AMBIENTAL, 11., 2004, Natal. Resumos... Natal: ABES/APESB/APRH, 2004.

ARTICULAÇÃO DO SEMIÁRIDO BRASILEIRO (ASA). Programa da Formação e Mobilização Social para a Convivência com o Semiárido: um milhão de cisternas rurais (P1MC). Recife: 2002. 47 p.

ARTICUlaÇÃO DO SEMIÁrido Brasileiro (ASA). Tanque de Pedra. 2014. Disponível em: $<$ http://plataforma.redesan.ufrgs.br/biblioteca/pdf bib.php?COD ARQUIVO=10442>. 24 p. Acesso em: 10 fev. 2020.

BERTALANFFY, L. V. General Theory of Systems. New York: George Braziller, 1968.

BRASIL. Ministério do Desenvolvimento Social (MDS). P1MC - ASA: impacto socioambiental do semiárido Brasileiro. Brasília: MDC, 2006.

BUCKLEY, W. Sociology and the Modern Systems Theory. New Jersey: Englewood Cliffs, 1967. 227 p..

COSTA FALCAO, C. L. Enclaves em meio ao semiárido nordestino: o maciço da Serra da Meruoca e o uso da terra. In: FALCAO SOBRINHO, J.; COSTA FALCAO, C. L.; SOUSA, R. N. R.; MOTA, F. A. (Org.). Semiárido: diversidades naturais e culturais. Sobral: IADE/UVA, 2008. 120 p.

DARROW, K. S.; SAXENIAN, M. Appropriate technology sourcebook: a guide to practical books for village and small community technology. Stanford: Volunteers in Asia, 1986. 
FALCAO SOBRINHO, J. O relevo como âncora da paisagem do vale, verde e cinza, do Acaraú, no Estado do Ceará. 2008. 245 f. Tese (Doutorado em Geografia Física) Faculdade de Filosofia, Letras e Ciências Humanas, Universidade de São Paulo, São Paulo, 2008.

FALCAO SOBRINHO, J. Relevo e paisagem: proposta metodológica. Sobral: Sobral Gráfica, 2009. 89 p.

FALCAO SOBRINHO, J. A Natureza do Vale do Acaraú: um olhar através das sinuosidades do relevo. Sobral: Editora SertãoCult, 2020. 199 p.

FALCÃO SOBRINHO, J.; COSTA FALCÃO, C. L.; PAIVA, A. M.; MENDES, M. V. R. Implantação e uso de cisternas de placas no semiárido cearense: o caso de Taperuaba, Sobral. Revista Homem, Espaço e Tempo, v. 1, p. 37-50, 2015.

FALCÃO SOBRINHO, J.; FALCÃO, C. L. C. Práticas agrícolas na Serra da Meruoca. Revista Essentia, Sobral, v. 1, p. 66-81, 2002.

FORD, J.; KESKITALO, E. C. H.; SMITH, T.; PEARCE, T.; BERRANG-FORD, L.; DUERDEN, F.; SMIT, B. Case study and analogue methodologies in climate change vulnerability research. WIREs Climate Change, v. 1, n. 3, p. 374-392, 2010.

FRAZÃO, Arthur. O que pode acontecer se beber água contaminada. Tua saúde. 2016. Disponível em: <https://www.tuasaude.com/consequencias-de-beber-aguacontaminada/>. Acesso em: 14 out. 2016.

FUNCEME. Dados pluviométricos do Estado do Ceará. Fortaleza: FUNCEME, 2016. Disponível em: < $\underline{w w w . f u n c e m e . c o m . b r}>$. Acesso em: 14 out. 2019.

GNADLINGER, J. Colheita de água de chuva em áreas rurais. Juazeiro: IRPAA, 2000. $40 \mathrm{p}$.

GNADLINGER, J. A., Contribuição da captação de água de chuva para o desenvolvimento sustentável do Semi-Árido Brasileiro - Uma abordagem focalizando o povo. In: SIMPÓSIO BRASILEIRO DE CAPTAÇÃO E MANEJO DE ÁGUA DE CHUVA, 3., 2001, Petrolina. Anais... Petrolina: 2001. v. 3. (CD-rom).

HERRERA, A. Notas sobre la ciencia y la tecnología en el desarrollo de la sociedad. In: HERRERA, A. (Org.). América Latina: ciencia y tecnología en el desarrollo de la sociedad. Santiago de Chile: Ed. Universitária, 1970. p.11-36.

HJERN, B.; PORTER, David O. Implementation structures: a new unit of administrative analysis. In: HILL, Michael J.; HAM, Christopher. The policy process in the modern capitalist state. 2. ed. New York: Prentice-Hall, 1993. p. 211-27.

NEGEV, A.; GIBSON, S. Archaeological encyclopedia of the Holy Land. Continuum International Publishing Group, 2001. Editorial Reviews.

NTALE, H. K.; MOSES, N. Improving the quality of harvested rainwater by using first flush interceptors/ retainers. In: PROCEEDINGS OF THE 11th INTERNATIONAL RAINWATER CATCHMENT SYSTEMS CONFERECE, 2003, México. Anais... México: University, 2003. 
PINEDA, G. Y. F. Gestão comunitária para abastecimento de água em áreas rurais: uma análise comparativa de experiências no Brasil e na Nicarágua. 2013. 204 f. Dissertação (Mestrado em Saneamento, Meio Ambiente e Recursos Hídricos) - Universidade Federal de Minas Gerais, Belo Horizonte, 2013.

PNUD - Programa das Nações Unidas para o Desenvolvimento. Relatório do desenvolvimento humano, 2006: a água para lá da escassez: poder, pobreza e a crise mundial da água. New York, USA: PNUD, 2006.

POCHMANN, M. O desafio da inclusão social no Brasil. São Paulo: Publisher Brasil, 2004. 164 p.

PONTES, E. T. M.; MACHADO, T. A. Programa um milhão de cisternas rurais no nordeste brasileiro: políticas públicas, desenvolvimento sustentável e convivência com o semiárido. In: ENCONTRO NACIONAL DE GEOGRAFIA AGRÁRIA, 19., 2009, São Paulo. Anais... São Paulo: USP, 2009. p. 1-15.

RUSKIN, R. R., Almacenaje de agua en cisternas 1a Parte: idea antigua para un mundo moderno. In: Água Latinoamérica, v. 1, n. 2, p. 13-16, 2001.

SCHIPPER, E. Conceptual history of adaptation in the UNFCCC Process. Review of European Community \& International Environmental Law, v. 15, n. 1, p. 82-92, 2006.

SENADO FEDERAL. Projeto de Lei do Senado nº 111. Brasília: Senado Federal, 2011.

SOUZA, M. J. N. Contribuição ao estudo das unidades morfo-estruturais do Estado do Ceará. Revista de Geologia, Fortaleza: Universidade Federal do Ceará, v. 1, p. 73-91, 1988.

UNEP - United Nations Environment Programe. Rainwater harvesting and utilisation an environmentally sound approach for sustainable urban water management: an introductory guide for decision-makers. UNEP: Technology Centre Newsletter and Technical, 2002.

UNICEF - United Nations Children's Fund. Harvesting the rain: a construction manual for cement rainwater jars and tanks. Bangkok, Thailand: East Asia and Pacific Regional Office, 2002.

WAHLIN, L. The family cistern: 3,000 years of household water collection. In: JORDAN, THE THIRD NORDIC CONFERENCE ON MIDDLE EASTERN STUDIES: Ethnic encounter and culture change, Joensuu, Finland, 1995. p. 19-22.

\title{
Como citar este artigo:
}

\begin{abstract}
ABNT
FALCÃO SOBRINHO, J. Water resources available at cisterns in the Acaraú River Basin, Ceará, Brazil. InterEspaço: Revista de Geografia e Interdisciplinaridade, v. 6, e202028, 2020. Disponível em: <http://dx.doi.org/10.18764/2446-6549.e202028>. Acesso em: 25 jan. 2020.
\end{abstract}




\section{APA:}

Falcão Sobrinho, J. (2020). Water resources available at cisterns in the Acaraú River Basin, Ceará, Brazil. InterEspaço: Revista de Geografia e Interdisciplinaridade, v. 6, e202028. Recuperado em 25 janeiro, 2020, de http://dx.doi.org/10.18764/2446-6549.e202028

\section{ccreative}

This is an open access article under the CC BY Creative Commons 4.0 license.

Copyright (C) 2020, Universidade Federal do Maranhão.

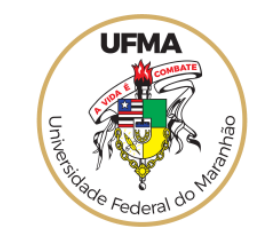

